\title{
Adrenomedullin and the calcitonin receptor-like receptor system mRNA expressions in the rat heart and sensory ganglia in experimentally-induced long-term diabetes
}

\author{
Eliska Mistrova $^{1,2}$, Silke Wiegand ${ }^{3}$, Jitka Sviglerova ${ }^{1,2}$, Uwe Pfeil ${ }^{3}$, Jitka Kuncova ${ }^{1,2}$, Jana \\ Slavikova ${ }^{1,2}$, Wolfgang Kummer ${ }^{3}$ and Magdalena Chottova Dvorakova ${ }^{1,2}$ \\ ${ }^{1}$ Department of Physiology, Faculty of Medicine in Pilsen, Charles University in Prague, Lidicka 1, 30100 Pilsen, Czech Republic \\ ${ }^{2}$ Biomedical Centre, Faculty of Medicine in Pilsen, Charles University in Prague, Lidicka 1, 30100 Pilsen, Czech Republic \\ ${ }^{3}$ Institute for Anatomy and Cell Biology, Excellence Cluster Cardio-Pulmonary System, Justus-Liebig-University, Aulweg \\ 123, 35385 Giessen, Germany
}

\begin{abstract}
Both adrenomedullin and calcitonin gene-related peptide (CGRP) regulate vascular tone in the heart, being cardioprotective in hypoxia. Additionally, adrenomedullin exhibits antiproliferative and antiapoptotic functions in the myocardium, while CGRP exerts positive chronotropic effect. Their actions are mediated through the specific $G$ protein-coupled receptor, CRLR, whose ligand affinity is determined by receptor activity modifying proteins RAMP1-3. CGRP binds to the complex formed by CRLR/RAMP1, whereas CRLR/RAMP2 and CRLR/RAMP3 serve as receptors for adrenomedullin. Here, we quantified expression of this signaling system in the rat heart and supplying sensory ganglia (dorsal root ganglia T1-T4 and vagal nodose ganglia) in streptozotocin-induced diabetes. In the course of diabetes, an increase of CRLR mRNA was noticed in the right ventricle 8 weeks and of RAMP3 mRNA in the left ventricle and right atrium 26 weeks after induction of diabetes. Relative expressions of other tested genes were not significantly altered. In the nodose vagal supplying specific cardiac afferents, but not in dorsal root ganglia which provide cardiac pain fibres, a small upregulation of CGRP expression was detected. In summary, the shifts observed in diabetes may favour a trend of a pronounced adrenomedullin signaling. These observations may provide a new possible therapeutic strategy for diabetic cardiomyopathy.
\end{abstract}

Key words: Adrenomedullin - Receptor activity modifying proteins - Heart - Sensory ganglia - Diabetes

\section{Introduction}

Adrenomedullin (AM) is a 52 amino acid peptide that was originally isolated from a human pheochromocytoma (Kitamura et al. 1993). It is synthesized and secreted by several organs including the heart (Hinson et al. 2000). AM shares components of the receptor system with calcitonin generelated peptide (CGRP), a neuropeptide released by primary sensory neurons in the heart. Both AM and CGRP regulate vascular tone in the heart (Gardiner et al. 1995) and exert

Correspondence to: Magdalena Chottova Dvorakova, Department of Physiology, Faculty of Medicine, Charles University, Lidicka 1, 30100 Pilsen, Czech Republic

E-mail: magdalena.dvorakova@lfp.cuni.cz positive inotropic effect (Ihara et al. 2000) Additionally, AM exhibits antiproliferative and antiapoptotic functions in the myocardium, and enhances NO production (Shimosawa et al. 2003), while CGRP has positive chronotropic effect (Saito et al. 1986). The receptors for these peptides consist of at least two protein components: the ligand-binding subunit, i.e. the calcitonin receptor-like receptor (CRLR), and one of three identified receptor activity modifying proteins (RAMP1-3) which determine the specificity of the receptor for a particular peptide. CGRP activates the CRLR/ RAMP1 complex, and AM appears to act as an agonist at CRLR/RAMP2 and CRLR/RAMP3 (Chakravarty et al. 2000). Physiological response of the heart to the CGRP/AM peptides is dependent on the levels of expression of CRLR and various RAMPs. 
Both AM gene transcription and AM peptide release in the heart were found to be profoundly stimulated by mechanical stretch (Tsuruda et al. 2000) and hypoxia (CormierRegard et al. 1998; Pfeil et al. 2006). AM in the heart serves a protective role as demonstrated in animal models with its transgenic or adenovirus-mediated overexpression and by AM delivery following myocardial infarction (Bunton et al. 2004). Specifically in diabetes, AM improves cardiac function and has been considered as a promising new therapeutic approach (Dobrzynski et al. 2002; Adeghate 2004). Except for a notion of fluctuating values of preproAM mRNA in the rat heart at 2 and 4 weeks (Tang et al. 2007) and unaltered expression in the left ventricle at 7 weeks after streptozotocin (STZ) administration (Ruzicska et al. 2004), it is currently unclear to which extent the endogenous cardiac AM signaling system is affected in the course of the disease, particularly in long-term diabetes.

On the background of these proposed links of AM to diabetic cardiomyopathy (Dobrzynski et al. 2002; Adeghate 2004; Tang et al. 2007) and to glucose-dependent neuronal damage (Tixier et al. 2008), we set out to determine gene expression of AM and the components of its receptor system in the various compartments of the rat heart (right and left atria and ventricles) in the course of STZ-induced long-term (8 and 26 weeks) diabetes. Since sensory neurons are also both target and source of AM/CGRP peptides (Cottrell et al. 2005; Hong et al. 2009) and are affected in long-term diabetes (Toth et al. 2007), we also investigated the expression of this signaling system in sensory ganglia providing the extrinsic innervation to the heart 26 weeks after STZ application.

\section{Materials and Methods}

\section{Experimental model of diabetes}

Adult female Wistar rats were purchased from VELAZ (Prague, Czech Republic). The animals were housed eight per cage, fed standard laboratory chow ad libitum with free access to drinking water. All animals were left intact to adapt for 2 weeks before the initiation of the experiments. All experiments were approved by the University Committee for Experiments on Laboratory Animals and were conducted in accordance with the "Guide for the Care and Use of Laboratory Animals” (NIH Publication No. 85-23, revised 1996) as well as the relevant Guidelines of the Czech Ministry of Agriculture for scientific experimentation on animals. All efforts were made to minimize the number of animals and their suffering throughout the experiment.

Diabetes was induced in animals at the age of 50 days by a single intravenous injection of STZ ( $65 \mathrm{mg} / \mathrm{kg}$ body weight; Sigma, St. Louis, MO) dissolved in citrate buffer ( $\mathrm{pH} 4.5$ ). To validate development of severe hyperglycemia, plasma glucose levels were measured by the glucose oxidase method (Bio-La-Test, Lachema, Czech Republic) before administration of STZ, 48 hours after STZ injection, and at the time point of killing of the animal. Animals with fasting glucose level above $18 \mathrm{mmol} / \mathrm{l}$ were considered to be diabetic and used for experiments.

Two groups of diabetic rats, 8 (STZ8) and 26 (STZ26) weeks after the onset of the disease, were studied. Control age-matched animals received a corresponding volume of vehicle and were also sacrificed 8 (C8) and 26 (C26) weeks after the injection. Totally, 23 controls and 24 STZ-treated animals were examined in the present study.

\section{Heart rate measurement}

Rats of both experimental groups were placed in a small chamber with electrodes in the floor that were connected to an electrocardiograph (EKG Seiva Praktik, Prague, Czech Republic). Animals were left to adapt for $20 \mathrm{~min}$, and then the resting heart rate was measured five times in one-minute intervals ( $n=6-10$ per each group). To estimate spontaneous heart frequency (without influence of sympathetic and parasympatetic innervation on the heart rate), an antagonist of the muscarinic acetylcholine receptors atropine $(4 \mathrm{mg} / \mathrm{kg}$ b.w., i.p.) and nonselective $\beta$-adrenergic receptor antagonist metipranolol ( $2 \mathrm{mg} / \mathrm{kg}$ b.w., i.p.) were administered and heart rate was measured again five times after 15 min adaptation period. The values presented in the results represent means of these measurements.

\section{Contraction experiments}

Animals were anaesthetized with intraperitoneal injection of urethane ( $1.5 \mathrm{~g} / \mathrm{kg}$ body weight) 10 minutes after having received heparin (500 U, i.p.) and their hearts were quickly excised ( $n=5-6$ per each group). Then the papillary muscles were dissected from the right ventricle and placed in an experimental chamber and attached to an isometric force transducer F30 (Hugo Sachs, Germany). The resting tension was set to reach $90-95 \%$ of maximum developed force at stimulation frequency of $1 \mathrm{~Hz}$. Double-chamber stimulation (stimulator Pulsemaster A300, WPI, USA) was used. The square-wave voltage pulses had duration of $1 \mathrm{~ms}$ and amplitude $\geq 50 \%$ above threshold. The preparation was perfused with $36^{\circ} \mathrm{C}$, oxygenated Tyrode solution (in mmol/l: $\mathrm{NaCl} 137, \mathrm{KCl} 4.5, \mathrm{MgCl}_{2} 1, \mathrm{CaCl}_{2} 2$, glucose 10, Hepes 5; $\mathrm{pH}$ adjusted to 7.4 with $\mathrm{NaOH}$ ) at a constant flow rate $(6-10 \mathrm{ml} / \mathrm{min})$. After a stabilization period (>30 minutes) the steady-state contractions at stimulation frequency $1 \mathrm{~Hz}$ were recorded and expressed in arbitrary units (a.u.). The resting tension was taken as zero. Data were recorded and analyzed using the data acquisition system DiSys (Merlin, Czech Republic). 
Gene expression analysis

Rats were anaesthetized with ether and killed by decapitation. Hearts from animals of all experimental groups and sensory ganglia from rats of C26 and STZ26 were rapidly excised and frozen in liquid N2 ( $n=6$ per each group). Prior to freezing, hearts were freed of fat and connective tissue and divided into the left atrium with the interatrial septum, right atrium, and free walls of both ventricles. Sensory ganglia to be analyzed were selected on the basis of previous neuroanatomical tracing studies demonstrating sources of rat cardiac afferents. Neuronal cell bodies of spinal afferents are predominantly located in dorsal root ganglia (DRG) at thoracic levels T1-T4 (Guić et al.2010). Perikarya of brainstem afferents are located in the vagal ganglion complex formed by the jugular and nodose ganglia (Hayakawa et al. 2011), for the sake of brevity designated "nodose ganglion" in this work. Accordingly, DRG T1-T4 and nodose ganglia were analyzed in this study.

Total RNA was isolated from each heart compartment of STZ-treated and control animals ( $n=6$ per group) using RNAzol B (WAK-Chemie, Bad-Soden, Germany). Ganglia were homogenized by a ball mill (Mixer Mill MM300, Retsch $\mathrm{GmbH}$, Haan, Germany) and total RNA was isolated using the RNeasy mini kit (Qiagen, Hilden, Germany). Contaminating DNA was destroyed with $1 \mathrm{U}$ DNase/ $\mu$ g total RNA (Invitrogen, Carlsbad, CA, USA). RNA was reverse transcribed using Superscript RNase H-Reverse Transcriptase II (200 U/onset; Invitrogen) for $50 \mathrm{~min}$ at $42^{\circ} \mathrm{C}$ and iScript (Bio-Rad, Munich, Germany) for $30 \mathrm{~min}$ at $52^{\circ} \mathrm{C}$ for heart samples and ganglia, respectively. Real-time quantitative PCR was done in the I-Cycler (Bio-Rad) using primers and SYBR Green PCR kit (Bio-Rad). The primers were designed to amplify the sequence corresponding to the published rat cDNA sequence for AM, CGRP, CRLR, RAMP1, RAMP2, RAMP3 and $\beta$-actin (see Table 1). All analyses were done in triplicate. The expression of AM, CGRP, CRLR, RAMP1, RAMP2, RAMP3 was normalized with $\beta$-actin as a control gene. The relative expression was calculated by comparison of the received $\mathrm{Cq}$ (quantification cycle) values as described previously (Skopek et al. 2012). Values obtained for groups STZ8 and STZ26 were compared with those for corresponding vehicle-injected and age-matched controls, respectively. Since cardiac CGRP originates to major extent from sensory neurons (Wharton et al. 1986), evaluation of its mRNA expression was done in the ganglia where the respective cell bodies are located but not in the heart itself. Control runs by omission of the RT step or by omission of template were negative.

\section{Data analysis}

Data from heart rate measurements and contraction experiments are presented as means \pm S.E.M. Statistical compari-
Table 1. Oligonucleotides used for RT-PCR

\begin{tabular}{llll}
\hline Target & Sequence $\left(5^{\prime} \rightarrow 3^{\prime}\right)$ & $\begin{array}{l}\text { Size } \\
(\mathrm{bp})\end{array}$ & $\begin{array}{l}\text { Accession } \\
\text { number }\end{array}$ \\
\hline$\beta$-actin & $\begin{array}{l}\text { tca tca cta tcg gca atg agc } \\
\text { ctc ctt ctg cat cct gtc agc }\end{array}$ & 209 & NM_031144.2 \\
\cline { 2 - 4 } AM & $\begin{array}{l}\text { gtc ttg gac ttt gcg ggt tt } \\
\text { taa cat cag ggc gat gga aa }\end{array}$ & 138 & NM_012715 \\
\cline { 2 - 4 } CGRP & $\begin{array}{l}\text { gtt ctc ccc ttt cct ggt tg } \\
\text { gct ccc tga ctt tca tct gc }\end{array}$ & 175 & NM_001033956 \\
\cline { 2 - 4 } CRLR & $\begin{array}{l}\text { caa cag cac gca tga gaa agt g } \\
\text { gta atc cgt tgg caa ctt agg c }\end{array}$ & 141 & NM_012717 \\
\cline { 2 - 4 } RAMP-1 & $\begin{array}{l}\text { cat gga gac cat agg gaa gac t } \\
\text { aga act tgt cca ctt ccg gat tg }\end{array}$ & 137 & AF181550 \\
\cline { 2 - 4 } RAMP-2 & $\begin{array}{l}\text { ctc cct ccg ctg tta ctg ct } \\
\text { tac cag caa ggt agg aca ttt gtt }\end{array}$ & 152 & AF181551 \\
\cline { 2 - 4 } RAMP-3 & $\begin{array}{l}\text { caa cct gtc gga gtt cat cgt } \\
\text { act gcc tat gga tac ccg tga t }\end{array}$ & 128 & NM_020100 \\
\hline
\end{tabular}

$\mathrm{AM}$, adrenomedullin; CGRP, calcitonin gene-related peptide; CRLR, calcitonin receptor-like receptor; RAMP, receptor activity modifying protein.

sons were made with the Student's $t$-test for unpaired (control $v s$. diabetic rats) data groups, after testing for normality of distribution. Statistical analysis of relative gene expression was done by Kruskal-Wallis test followed by Mann-Whitney test using SPSS software (SPSS software, Munich, Germany). Throughout, the results were considered significantly different when $p<0.05$.

\section{Results and Discussion}

To evaluate the effect of diabetes mellitus on AM/CGRP signaling system we used a well-defined animal model based on the application of STZ, which causes selective destruction of the pancreatic $\beta$-cells within $24 \mathrm{~h}$ after the administration of the diabetogenic agent. This leads to hyperglycemia and hypoinsulinemia in the treated animals (Rakieten et al. 1963).

In the present study, fasting serum glucose levels were $5.0 \pm 0.9 \mathrm{mmol} / \mathrm{l}$ in vehicle-treated rats $(n=21)$, and were $24.9 \pm 3.1 \mathrm{mmol} / \mathrm{l}$ in STZ-treated rats after 8 weeks $(n=12)$, and $22.4 \pm 2.0 \mathrm{mmol} / \mathrm{l}$ in STZ-treated rats after 26 weeks ( $n=11$; data given as means \pm S.D.). STZ-diabetic rats had significantly lower body weights than vehicle-treated controls $(p<0.0001$; Table 2$)$.

In order to evaluate the effects of STZ application on the basic heart functions, cardiac contractility and resting heart rate were measured. Additionally, we tested the spontaneous heart rate (in the absence of sympathetic and parasympathetic activities). STZ diabetes significantly decreased the 
Table 2. Plasma glucose levels and body weights of rats receiving vehicle (Control) or STZ treatment (Diabetes)

\begin{tabular}{lccc}
\hline & & Control & Diabetes \\
\hline Plasma glucose & $8 \mathrm{w}$ & $4.89 \pm 0.81$ & $24.92 \pm 3.09^{*}$ \\
(mmol/l) & $26 \mathrm{w}$ & $5.16 \pm 0.98$ & $22.44 \pm 2.02^{\star}$ \\
\cline { 2 - 4 } Body weight & $8 \mathrm{w}$ & $220 \pm 9.6$ & $168 \pm 15.3^{\star}$ \\
(g) & $26 \mathrm{w}$ & $239 \pm 13.3$ & $170 \pm 12.8^{*}$ \\
\hline
\end{tabular}

Data are expressed in mean \pm S.D.; $n=10-12$ per group. ${ }^{\star} p<0.0001$ STZ vs. age-matched controls. w, weeks.

contraction force (CF) of the right papillary muscle at both time points, i.e. 8 and 26 weeks after the induction of diabetes. In the control group, CF (at stimulation frequency $1 \mathrm{~Hz}$ ) was $49 \pm 5.1$ arbitrary units (a.u.) 8 weeks and $47 \pm 2.8$ a.u. 26 weeks after the beginning of the experiment, whereas in STZ rats CF was $26 \pm 3.1$ a.u. and $23 \pm 2.9$ a.u., respectively (Fig. 1A).

The resting heart rate did not change significantly with age, reaching $334 \pm 7$ beats per minute (bpm) in C8 rats and $322 \pm 6 \mathrm{bpm}$ in C26 animals. STZ treatment led to a significant reduction of the resting heart rate; diabetic rats had $248 \pm 7$ and $245 \pm 9$ bpm 8 and 26 weeks after STZ administration, respectively. After the blockade of sympathetic and parasympathetic activities, heart rate increased in controls to $364 \pm 6$ and $363 \pm 6 \mathrm{bpm}$, respectively, and in diabetic animals to $269 \pm 5$ and $261 \pm 5$ bpm (Fig. 1B). The results show that in the absence of autonomic nervous system modulation, heart rate of STZ-treated animals has increased significantly less than in controls, which indicates impairment of this innervation.

\section{Expression of genes}

\section{Heart}

In control hearts, mRNAs coding for AM, CRLR, RAMP1, RAMP2 and RAMP3 were detected in all heart chambers without any noticeable differences between atria and ventricles, or right and left side, respectively. Out of all these genes, AM, RAMP2 and CRLR exhibited strong expression in approximately similar range. Expression of mRNAs for RAMP1 and RAMP3 was significantly lower (app. 5\%) than that of RAMP2 in all heart compartments, and did not differ between each other (Fig. 2).

In the course of diabetes, significant increase of CRLR mRNA was seen in the right ventricle (4-fold) 8 weeks (Fig. 3), and RAMP3 mRNA rose in the left ventricle (3-fold) and right atrium (2-fold) 26 weeks after induction of diabetes (Figs. 4 and 5). Additionally, some tendency to increased expression of mRNA for RAMP3 and downregulation of RAMP2 in the right atrium and upregulation of RAMP1 and RAMP2 in the left ventricle of 8 week STZ groups were noted but statistical significance was not reached.

In the heart, $A M$ is secreted from vascular smooth muscle cells, endothelial cells and fibroblasts and acts here as a paracrine factor with important role in regulating cardiovascular homeostasis (Hinson et al. 2000). Our study has show that expression of mRNA for AM is similar in all heart compartments. AM is involved in the control of cardiac function, where it has a positive inotropic effect and increases cardiac output (He et al. 2007; Ihara et al. 2000) and, additionally, it has inhibitory actions on cardiac myocytes hypertrophy
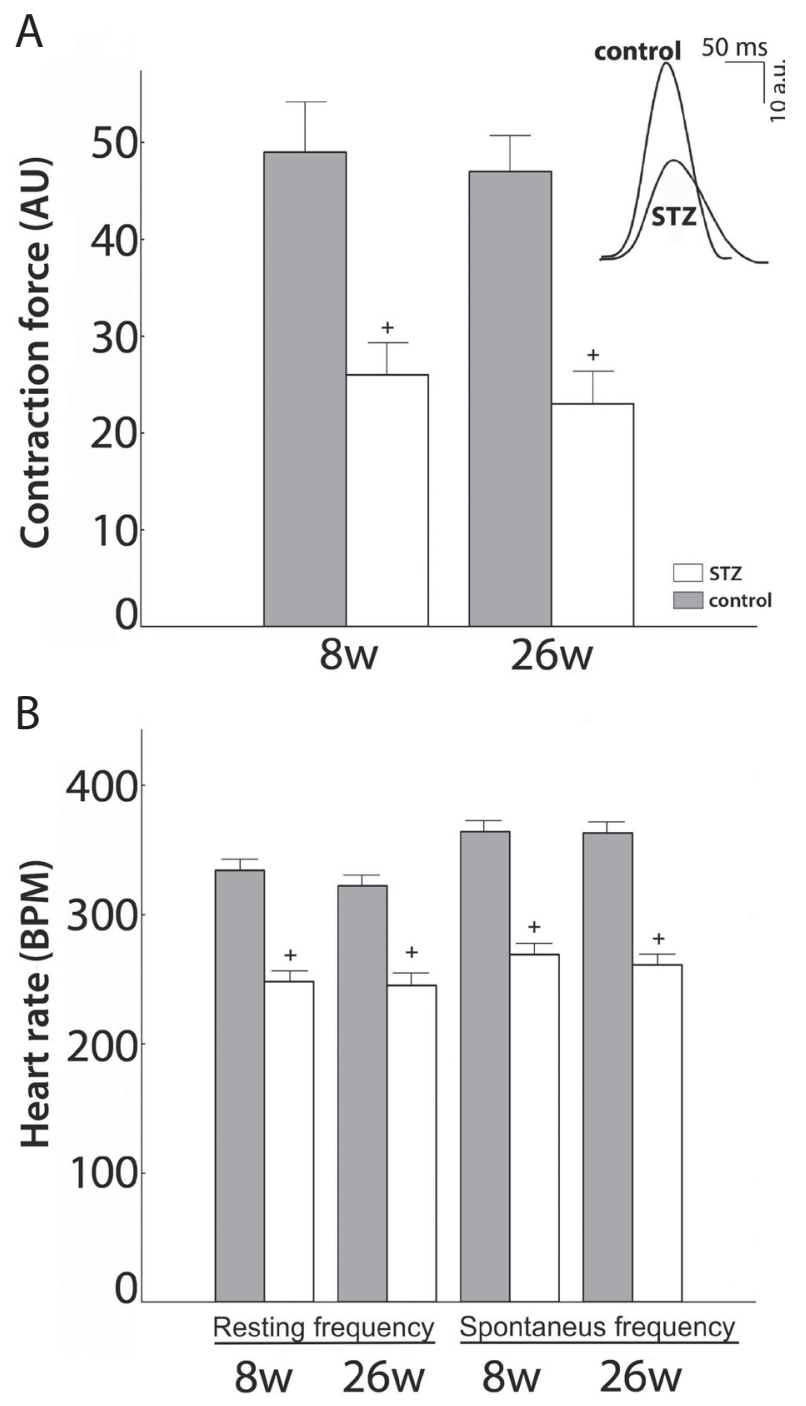

Figure 1. A. Contraction force at stimulation frequency $1 \mathrm{~Hz}$. ${ }^{+} p<0.05$, compared to the respective control value. Inset: Contraction force at stimulation frequency $1 \mathrm{~Hz}$ in control and STZ-treated rats. B. Resting and spontaneous heart rates in controls and STZtreated rats. ${ }^{+} p<0.05$, compared to the corresponding control value. $8 \mathrm{w}, 8$ weeks; $26 \mathrm{w}, 26$ weeks; AU, arbitrary units. 
and fibroblast proliferation (Tsuruda et al. 1998; Horio et al. 1999). Expression and role of AM has been studied in a wide range of pathological states. In many cardiovascular disorders, expression of AM was increased, e.g. in hypertension (Pan et al. 2006), congestive heart failure (Jougasaki et al. 1996; Oie et al. 2000), cardiac ischemia (Oie et al. 2000) and short time diabetes (He et al. 2007; Tang et al. 2007). Most of these pathologies are associated with increased plasma levels of AM that are related to disease severity (Brain and Grant 2004). Elevation of AM plasma level has been noticed also in patients with diabetes (García-Unzueta et al. 1998). STZ treatment of rats led to an increased AM mRNA expression in heart ventricles but not in the atria 2 and 4 weeks after the application. Interestingly, this increase was not paralleled by an increase in AM peptide content (Tang et al. 2007). AM has been reported to act in an autocrine/paracrine fashion to prevent cardiovascular damage (Shimekake et al. 1995). In our study, long-term diabetes did not cause any change in AM mRNA production in any heart compartment, but affected expression of its receptor system.

AM acts throughout two specific receptors formed by the CRLR and RAMP2 or RAMP3. Oie et al. (2005) showed that both of these heterodimers are present in the heart, but CRLR/RAMP2 predominates. This is in agreement with our results showing approximately 20 -fold higher expression of RAMP2 than RAMP3 in all heart compartments of intact rats. A tendency of AM protein binding to vary with RAMP2 mRNA levels, but not with RAMP3 mRNA levels in various rat tissues was already described (Chakravarty et al. 2000). STZ treatment caused transient upregulation of CRLR gene
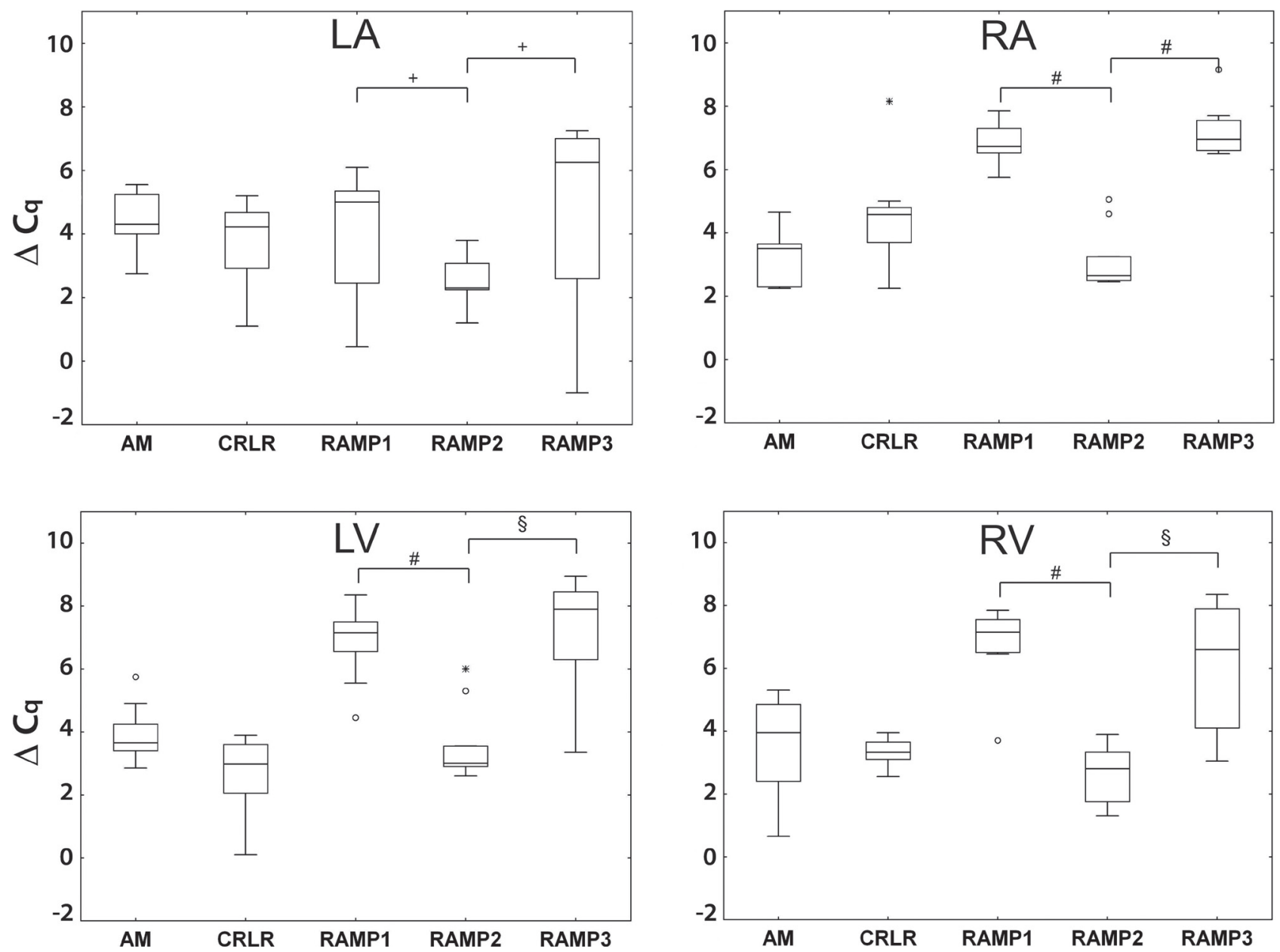

Figure 2. Real-time RT-PCR, hearts of control animals. Percentiles 0, 25, 50, 75 and 100 are presented in box plots; small circles and asterisks represent single data beyond $3 \times$ S.D. Data are presented as $\Delta \mathrm{C}_{\mathrm{q}}$ values (compared to $\beta$-actin) to indicate differences in expression between different targets in separated heart compartments. Hence, low values represent high expression. ${ }^{+} p<0.05 ;{ }^{\S} p<0.0005$; ${ }^{\#} p<0.0001$. LA, left atrium; RA, right atrium; LV, left ventricle; RV, right ventricle; AM, adrenomedullin; CRLR, calcitonin receptor like receptor; RAMP, receptor activity modifying protein. 
in the right ventricle 8 weeks after the onset of the disease, which is in agreement with our previous results (Chottova Dvorakova et al. 2005).

Recent results show that expression of RAMPs is differently regulated in the heart in various cardiovascular diseases. Congestive heart failure caused elevation of cardiac expression of RAMP2 (Totsune et al. 2000). Conversely, chronic heart failure (induced by aortic stenosis) is associated with mRNA as well as protein overexpression of RAMP1 and RAMP3 but not RAMP2 in both atria and ventricles (Cueille et al. 2002). Several other models of hypertension caused upregulation of RAMP3 in the cardiovascular system (Nishikimi et al. 2003; Pan et al. 2006; Zhao et al. 2006). These differences in the expression of RAMPs under various pathological conditions suggest distinct roles for receptors, which they form.

Diabetic cardiomyopathy is defined as a disease process which affects the myocardium in diabetic patients causing a wide range of structural abnormalities eventually leading to left ventricular hypertrophy and diastolic and systolic dysfunction (Hayat et al. 2004). Various rat models with left ventricular hypertrophy exhibit overexpression of AM, RAMP2 and RAMP3 (Kuwasako et al. 2011). Our result show that, among members of the AM/CGRP signaling system, mainly RAMP3 expression is altered in the heart affected by long-term diabetes. Since RAMP3 is considered as a cardioprotective factor via enhancing AM signaling during cardiovascular stress (Gibbons et al. 2007), this anticipated protective role may also operate in the diabetic heart.

\section{Sensory ganglia}

Cell bodies of primary afferent neurones providing sensory nerve fibres to the rat heart are localized in the upper thoracic (T1-T4) dorsal root ganglia (DRG) and the vagal sensory nodose ganglia (Guić et al. 2010, Hayakawa et al. 2011). In both types of ganglia, CGRP mRNA was orders of magnitudes higher than AM mRNA, judged by $\Delta \mathrm{Cq}$ values with $\beta$-actin serving as reference gene. For the components of the receptor system, rank order of expression
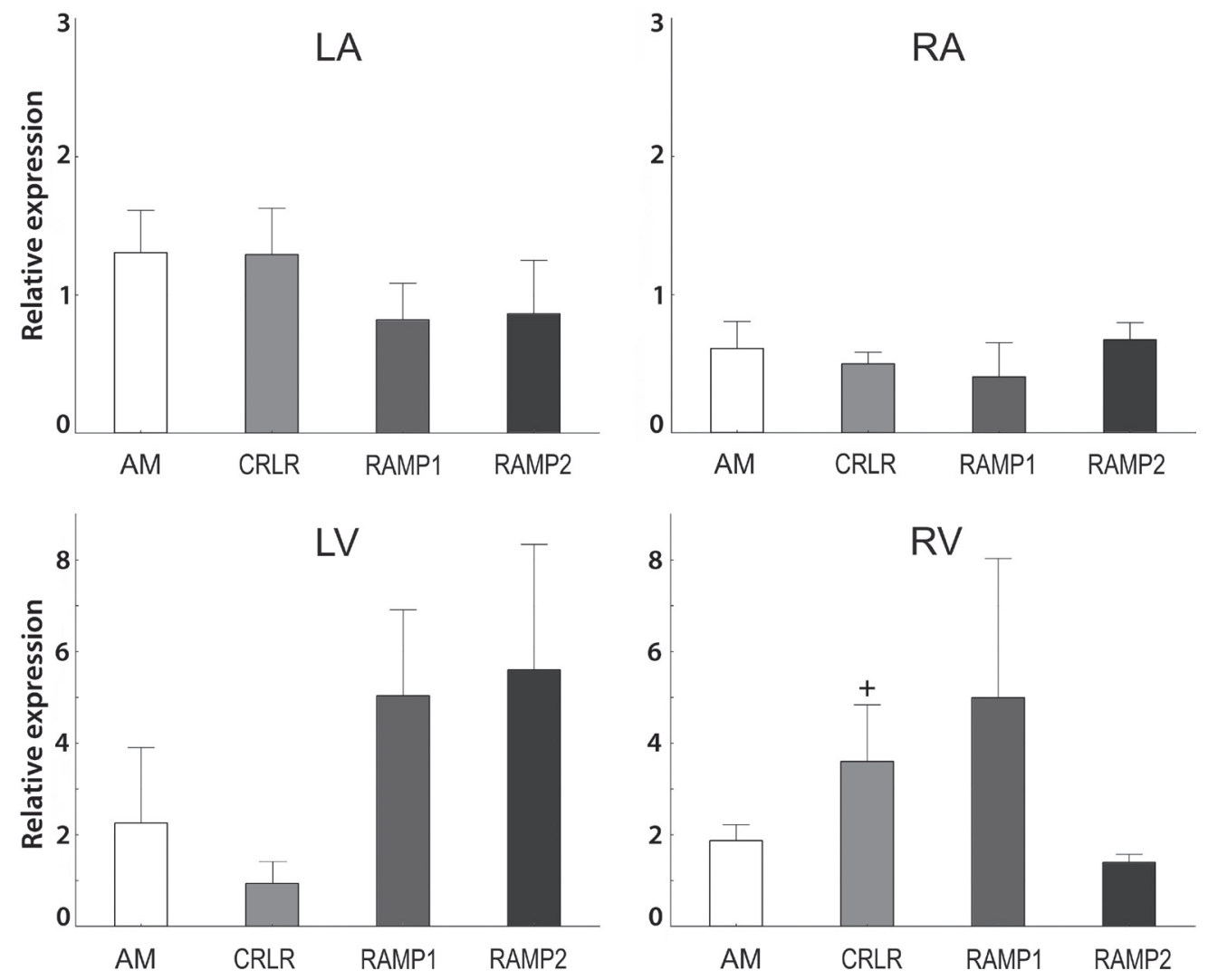

Figure 3. Real-time RT-PCR, effect of STZ treatment on expression of different targets in separated heart compartments - 8 weeks after application. Control values of the appropriate heart compartments were used as comparators and were settled as 1 . The bars represent the means of the relative expression levels determined for each mRNA with standard errors of the mean. ${ }^{+} p<0.05$. For abbreviations see Fig. 2. 
was RAMP3 $>$ RAMP2 $>$ CRLR $>$ RAMP1 in DRG and RAMP3 $>$ RAMP2 $>$ CRLR $=$ RAMP1 in nodose ganglia of intact animals (Fig. 6).

The sensory innervation of the heart is impaired in diabetic patients, which may lead to painless myocardial ischemia (Adeghate 2004). Cardiac pain is transmitted by the spinal afferents with their cell bodies located in upper thoracic DRG, and their stimulation causes reflex tachycardia and rise in blood pressure (Fu and Longhurst 2009). It has been reported that STZ-induced diabetes mellitus causes downregulation of CGRP mRNA in sensory neurones of rat lumbar DRG 6 weeks and 12 months after STZ administration (Rittenhouse et al. 1996; Zochodne et al. 2001). This is not paralleled by our data on thoracic DRG 26 weeks after STZ treatment showing unaltered expression of the AM/CGRP signaling system. In line with the persistent high expression of CGRP mRNA in these DRG, we have previously demonstrated that CGRP content of all four heart compartments is not reduced but rather slightly enhanced 16 weeks after STZ injection (Chottova Dvorakova et al. 2005). This adds to the notion that the impact of diabetes on neuronal CGRP expression and content is organ specific as it increases in skin (Karanth et al. 1990) and iris (Marfurt and Echtenkamp 1995), decreases in ileum (Belai et al. 1996), and remains unaltered in cornea (Marfurt and Echtenkamp 1995).

Sensory neurons of vagal ganglia are not considered to convey specific cardiac sensory modalities such as myocardial stretch to the brainstem rather than being involved in cardiac pain perception (Fu and Longhurst 2009). Nonetheless, a population of rat vagal cardiac afferent contains CGRP (Hayakawa et al. 2011). In contrast to spinal (DRG) afferents, the stimulation of this vagal pathway results in a decrease in heart rate and blood pressure (Fu and Longhurst 2009). This functionally, and to a large extent also embryonically distinct set of sensory neurons responded slightly different to long-term diabetes than thoracic DRG neurons. In our study, STZ treatment caused a small (1.4-fold) but significant upregulation in CGRP mRNA in the nodose ganglion (Fig. 7). Such an increase may be either due to upregulation at the level of
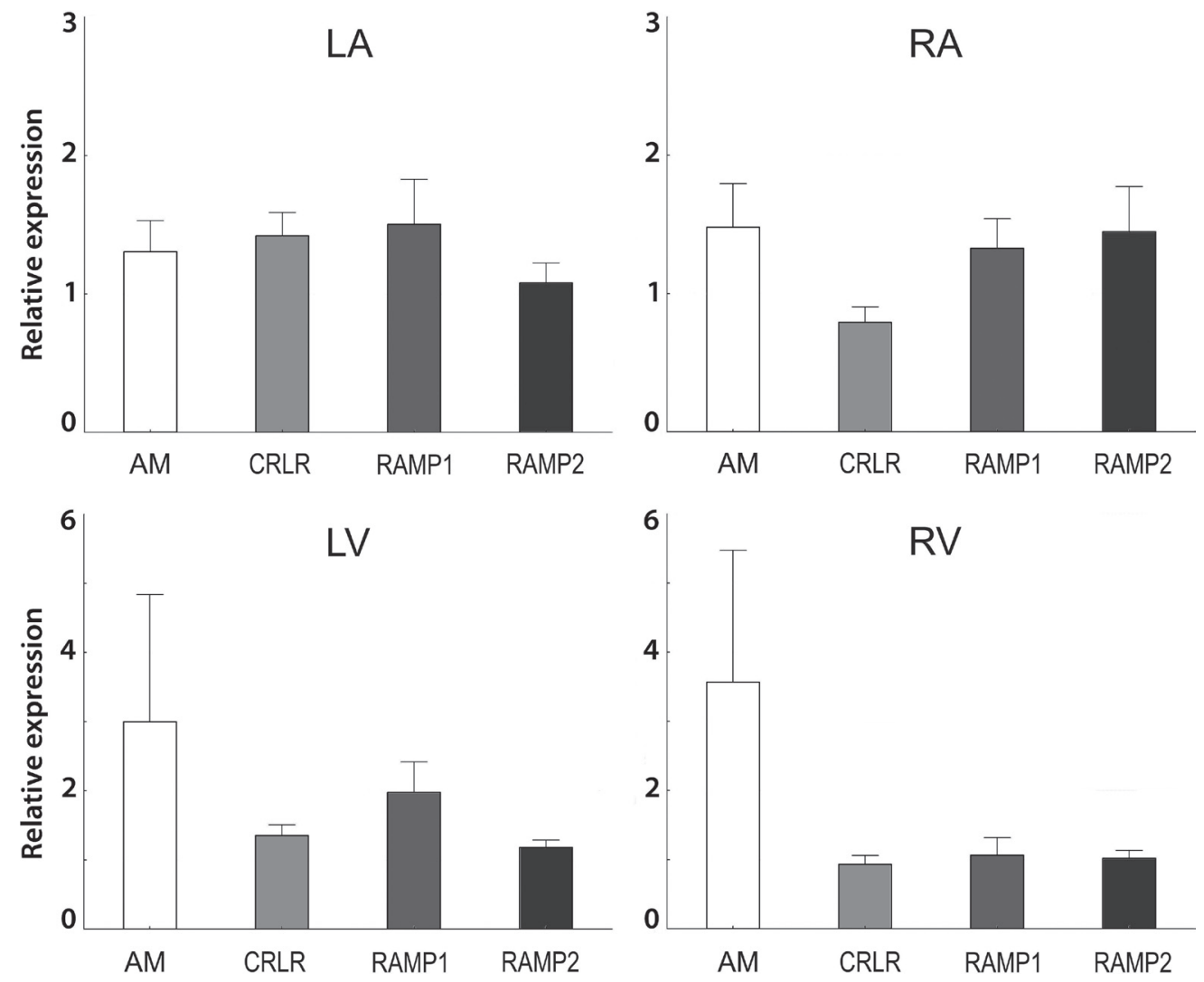

Figure 4. Real-time RT-PCR, effect of STZ treatment on expression of different targets in separated heart compartments - 26 weeks after application. Control values of the appropriate heart compartments were used as comparators and were settled as 1 . The bars represent the means of the relative expression levels determined for each mRNA with standard errors of the mean. For abbreviations see Fig. 2. 
already CGRP expressing neurons, or, as it is the case in allergic airway inflammation, by de novo expression in neurons that previously had not expressed this neuropeptide (Fischer et al. 1996). Since the number of CGRP-immunoreactive neurons in rat sensory vagal ganglia has been reported to keep constant even 24 weeks after STZ injection (Regalia et al. 2002), we favour a slight upregulation at individual neuron level rather than recruitment as being the cause of the presently observed enhanced CGRP mRNA content.

In general, AM expression in sensory neurons is also susceptible to plasticity, e.g. it increases in DRG neurons within hours after injection of complete Freund's adjuvant (CFA) into the rat hind paw (Hong et al. 2009). AM is
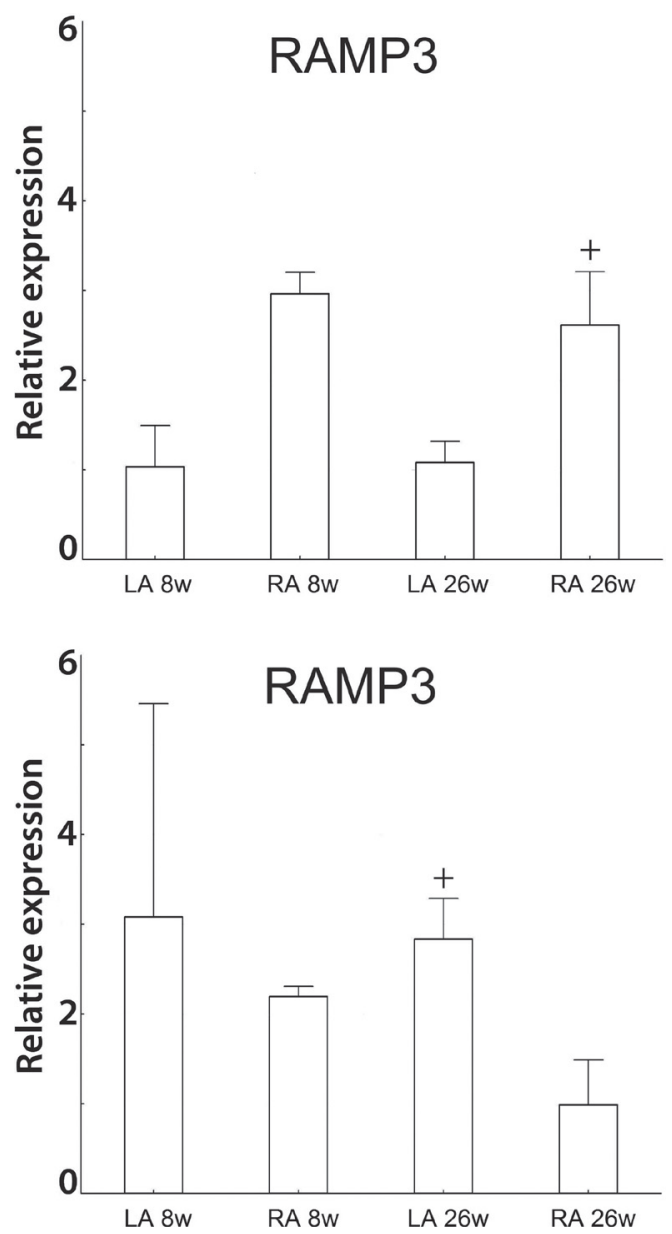

Figure 5. Real-time RT-PCR, effect of STZ treatment on expression of RAMP3 mRNA in separated heart compartments -8 and 26 weeks after application. Control values of the appropriate heart compartments were used as comparators and were settled as 1 . The bars represent the means of the relative expression levels determined for each mRNA with standard errors of the mean. ${ }^{+} p<0.05$. w, week. For other abbreviations see Fig. 2.
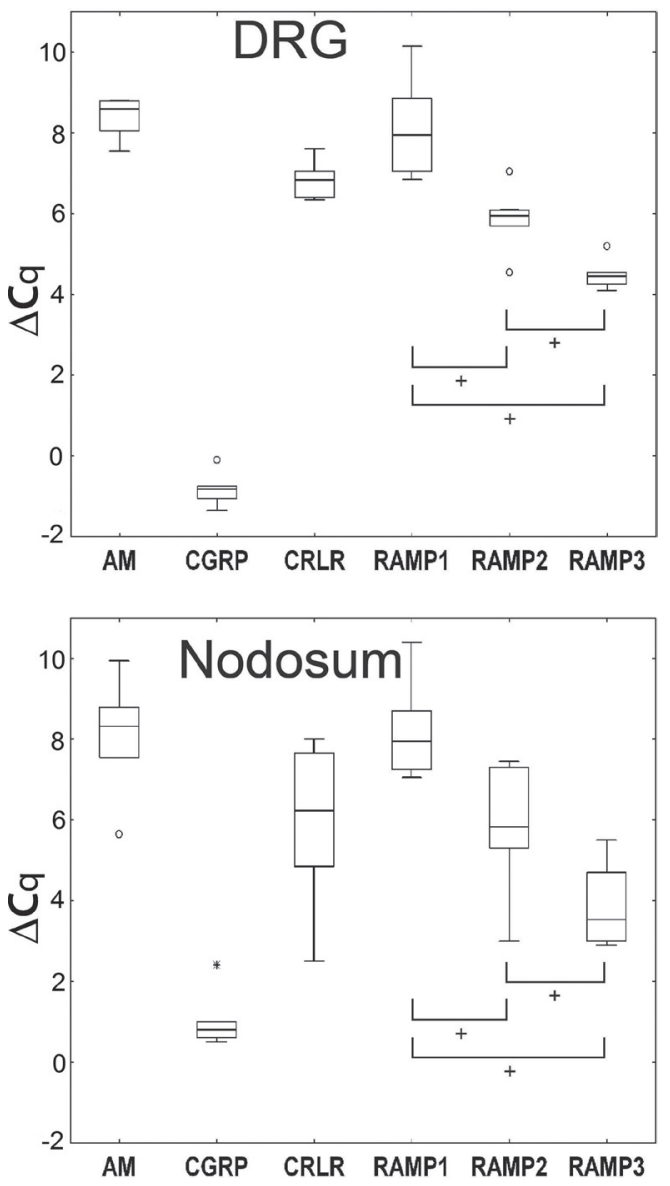

Figure 6. Real-time RT-PCR, DRG and nodose ganglia of control animals. Percentiles 0, 25, 50, 75 and 100 are presented in box plots; small circles and asterisks represent single data beyond $3 \times$ S.D. Data are presented as $\Delta \mathrm{C}_{\mathrm{q}}$ values (compared to $\beta$-actin) to indicate differences in expression between different targets in separated heart compartments. Hence, low values represent high expression. ${ }^{+} p<0.05$. DRG, dorsal root ganglia; CGRP, calcitonin gene-related peptide. For other abbreviations see Fig. 2.

coexpressed with CGRP in DRG neurons (Fernández et al. 2010), and it influences CGRP expression as CGRP content is diminished in DRG from neuron specific AM knockout mice (Fernández et al. 2010) and the blockade of AM receptors abrogates changes in CGRP expression in the hind paw-CFA model (Hong et al. 2009). We are not aware, however, on previous reports on AM expression and potential regulation in vagal sensory neurons. As the present data show, AM mRNA levels in the vagal sensory ganglion are equivalent to those in upper thoracic DRG and are unaffected in long-term diabetes at both locations. Hence, changes in AM expression are unlikely the triggers for the slight upregulation of CGRP mRNA in sensory vagal ganglia. 

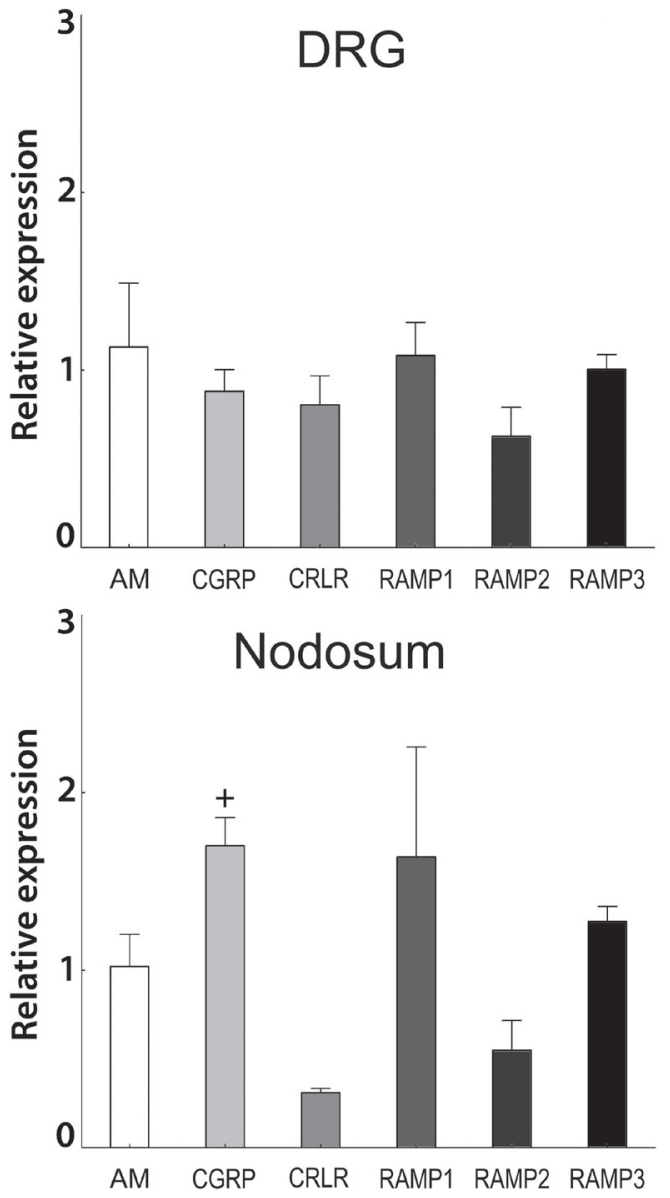

Figure 7. Real-time RT-PCR, effect of STZ treatment on expression of different targets in DRG and nodose ganglia - $26 \mathrm{w}$ after application. Control values of the appropriate ganglion were used as comparators and were settled as 1 . The bars represent the means of the relative expression levels determined for each mRNA with standard errors of the mean. ${ }^{+} p<0.05$. For abbreviations see Fig. 6 .

\section{Conclusion}

In the course of diabetes, expression of RAMP3 is, out of all evaluated members of AM/CGRP signaling system, mainly affected in the heart. Upregulation of receptors for $\mathrm{AM}$ in the heart of animals with long-term diabetes would be an explanation for therapeutic effect of AM in such state, which has been already postulated (Dobrzynski et al. 2002). It might be a promising option for the treatment of deleterious effects of diabetic state. To obtain more information about cell types in the heart mainly affected by the disease, further experiments using laser microdissection are required.

Acknowledgement. This work has been supported by GAUK 99510, Charles University Research Fund (project number P36), by the project ED2.1.00/03.0076 from European Regional Development Fund, and DFG, 436 TSE 113/51/0-1.

\section{References}

Adeghate E. (2004): Molecular and cellular basis of the aetiology and management of diabetic cardiomyopathy: a short review. Mol. Cell. Biochem. 261, 187-191 http://dx.doi.org/10.1023/B:MCBI.0000028755.86521.11

Belai A., Calcutt N. A., Carrington A. L., Diemel L. T., Tomlinso D. R., Burnstock C. (1996): Enteric neuropeptides in streptozotocin-diabetic rats; effects of insulin and aldose reductase inhibition. J. Auton. Nerv. Syst. 58, 163-169 http://dx.doi.org/10.1016/0165-1838(95)00129-8

Brain S. D., Grant A. D. (2004): Vascular actions of calcitonin gene-related peptide and adrenomedullin. Physiol. Rev. 84, 903-934 http://dx.doi.org/10.1152/physrev.00037.2003

Bunton D. C., Petrie M. C., Hillier C., Johnston F., McMurray J. J. (2004): The clinical relevance of adrenomedullin: a promising profile? Pharmacol. Ther. 103, 179-201 http://dx.doi.org/10.1016/j.pharmthera.2004.07.002

Chakravarty P., Suthar T. P., Coppock H. A., Nicholl C. G., Bloom S. R., Legon S., Smith D. M. (2000): CGRP and adrenomedullin binding correlates with transcript levels for calcitonin receptorlike receptor (CRLR) and receptor activity modifying proteins (RAMPs) in rat tissues. Br. J. Pharmacol. 130, 189-195 http://dx.doi.org/10.1038/sj.bjp.0702975

Chottova Dvorakova M., Kuncova J., Pfeil U., McGregor G. P., Sviglerova J., Slavikova J., Kummer W. (2005): Cardiomyopathy in streptozotocin-induced diabetes involves intra-axonal accumulation of calcitonin gene-related peptide and altered expression of its receptor in rats. Neuroscience 134, 51-58 http://dx.doi.org/10.1016/j.neuroscience.2005.03.058

Cormier-Regard S., Nguyen S. V., Claycomb W. C. (1998): Adrenomedullin gene expression is developmentally regulated and induced by hypoxia in rat ventricular cardiac myocytes. J. Biol. Chem. 273, 17787-17792 http://dx.doi.org/10.1074/jbc.273.28.17787

Cottrell G. S., Roosterman D., Marvizon J. C., Song B., Wick E., Pikios S., Wong H., Berthelier C., Tang Y., Sternini C., Bunnett N. W., Grady E. F. (2005): Localization of calcitonin receptorlike receptor and receptor activity modifying protein 1 in enteric neurons, dorsal root ganglia, and the spinal cord of the rat. J. Comp. Neurol. 490, 239-255

http://dx.doi.org/10.1002/cne.20669

Cueille C., Pidoux E., de Vernejoul M. C., Ventura-Clapier R., Garel J. M. (2002): Increased myocardial expression of RAMP1 and RAMP3 in rats with chronic heart failure. Biochem. Biophys. Res. Commun. 294, 340-346 http://dx.doi.org/10.1016/S0006-291X(02)00487-4

Dobrzynski E., Montanari D., Agata J., Zhu J., Chao J., Chao L. (2002): Adrenomedullin improves cardiac function and prevents renal damage in streptozotocin-induced diabetic rats. Am. J. Physiol. Endocrinol. Metab. 283, E1291-1298

Fernández A. P., Serrano J., Martínez-Murillo R., Martínez A. (2010): Lack of adrenomedullin in the central nervous system 
results in apparently paradoxical alterations on pain sensitivity. Endocrinology 151, 4908-4915 http://dx.doi.org/10.1210/en.2010-0121

Fischer A., McGregor G. P., Saria A., Philippin B., Kummer W. (1996): Induction of tachykinin gene and peptide expression in guinea pig nodose primary afferent neurons by allergic airway inflammation. J. Clin. Invest. 98, 2284-2291 http://dx.doi.org/10.1172/JCI119039

Fu L. W., Longhurst J. C. (2009): Regulation of cardiac afferent excitability in ischemia. Handb. Exp. Pharmacol. 194, 185-225 http://dx.doi.org/10.1007/978-3-540-79090-7_6

García-Unzueta M. T., Montalban C., Pesquera C., Berrazueta J. R., Amado J. A. (1998): Plasma adrenomedullin levels in type 1 diabetes. Relationship with clinical parameters. Diabetes Care 21, 999-1003 http://dx.doi.org/10.2337/diacare.21.6.999

Gardiner S. M., Kemp P. A., March J. E., Bennett T. (1995): Regional haemodynamic effects of human and rat adrenomedullin in conscious rats. Br. J. Pharmacol. 114, 584-591 http://dx.doi.org/10.1111/j.1476-5381.1995.tb17179.x

Gibbons C., Dackor R, Dunworth W., Fritz-Six K., Caron K. M. (2007): Receptor activity-modifying proteins: RAMPing up adrenomedullin signaling. Mol. Endocrinol. 21, 783-796 http://dx.doi.org/10.1210/me.2006-0156

Guić M. M., Kosta V., Aljinović J., Sapunar D., Grković I. (2010): Characterization of spinal afferent neurons projecting to different chambers of the rat heart. Neurosci. Lett. 469, 314-318 http://dx.doi.org/10.1016/j.neulet.2009.12.016

Hayat S. A., Patel B., Khattar R. S., Malik R. A. (2004): Diabetic cardiomyopathy: mechanisms, diagnosis and treatment. Clin. Sci. (Lond) 107, 539-557 http://dx.doi.org/10.1042/CS20040057

Hayakawa T., Kuwahara-Otani S., Maeda S., Tanak K., Seki M. (2011): Projections of calcitonin gene-related peptide immunoreactive neurons in the vagal ganglia of the rat. J. Chem. Neuroanat. 41, 55-62 http://dx.doi.org/10.1016/j.jchemneu.2010.11.003

Hinson J. P., Kapas S., Smith D. M. (2000): Adrenomedullin, a multifunctional regulatory peptide. Endocr. Rev. 21, 138-167

He R. X., Gu C. L., Shen F., Zhang X. M. (2007): Changes in expression of adrenomedullin in the myocardium of streptozotocin-induced diabetic rats. Chin. Med. J. (Engl) 120, 187-191

Hong Y., Liu Y., Chabot J. G, Fournier A., Quirion R. (2009): Upregulation of adrenomedullin in the spinal cord and dorsal root ganglia in the early phase of CFA-induced inflammation in rats. Pain 146, 105-113 http://dx.doi.org/10.1016/j.pain.2009.07.015

Horio T., Nishikimi T., Yoshihara F., Matsuo H., Takishita S., Kangawa K. (1999): Effects of adrenomedulin on cultured rat cardiac myocytes and fibroblasts. Eur. J. Pharmacol. 382, 1-9 http://dx.doi.org/10.1016/S0014-2999(99)00559-2

Ihara T., Ikeda U., Tate Y., Ishibashi S., Shimada K. (2000): Positive inotropic effects of adrenomedullin on rat papillary muscle. Eur. J. Pharmacol. 390, 167-172 http://dx.doi.org/10.1016/S0014-2999(00)00011-X

Jougasaki M., Rodeheffer R. J., Redfield M. M., Yamamoto K., Wei C. M., McKinley L. J., Burnett J. C. Jr. (1996): Cardiac secre- tion of adrenomedullin in human heart failure. J. Clin. Invest. 97, 2370-2376 http://dx.doi.org/10.1172/JCI118680

Karanth S. S., Springall D. R., Francavilla S., Mirrlees D. J., Polak J. M. (1990). Early increase in CGRP- and VIP-immunoreactive nerves in the skin of streptozotocin-induced diabetic rats. Histochemistry 94, 659-666 http://dx.doi.org/10.1007/BF00271994

Kitamura K., Kangawa K., Kawamoto M., Ichiki Y., Nakamura S., Matsuo H., Eto T. (1993): Adrenomedullin: A novel hypotensive peptide isolated from human pheochromocytoma. Biochem. Biophys. Res. Commun. 192, 553-560 http://dx.doi.org/10.1006/bbrc.1993.1451

Kuwasako K., Kitamura K., Nagata S., Hikosaka T., Takei Y., Kato J. (2011): Shared and separate functions of the RAMP-based adrenomedullin receptors. Peptides 32, 1540-1550 http://dx.doi.org/10.1016/j.peptides.2011.05.022

Marfurt C. F., Echtenkamp S. F. (1995): The effect of diabetes on neuropeptide content in the rat cornea and iris. Invest. Ophthalmol. Vis. Sci. 36, 1100-1106

Nishikimi T., Tadokoro K., Mori Y., Wang X., Akimoto K., Yoshihara F., Minamino N., Kangawa K., Matsuoka H. (2003): Ventricular adrenomedullin system in the transition from LVH to heart failure in rats. Hypertension 41, 512-518 http://dx.doi.org/10.1161/01.HYP.0000053447.64213.C4

Oie E., Vinge L. E., Yndestad A., Sandberg C., Grogaard H. K., Attramadal H. (2000): Induction of a myocardial adrenomedullin signaling system during ischemic heart failure in rats. Circulation 101, 415-422 http://dx.doi.org/10.1161/01.CIR.101.4.415

Oie E., Vinge L. E., Andersen G. O., Yndestad A., Krobert K. A., Sandberg C., Ahmed M. S., Haug T., Levy F. O., Skomedal T., Attramadal H. (2005): RAMP2 and RAMP3 mRNA levels are increased in failing rat cardiomyocytes and associated with increased responsiveness to adrenomedullin. J. Mol. Cell. Cardiol. 38, 145-151 http://dx.doi.org/10.1016/j.yjmcc.2004.10.009

Pan C. S., Jiang W., Wu S. Y., Zhao J., Pang Y. Z., Tang C. S., Qi Y. F. (2006): Potentiated response to adrenomedullin in myocardia and aortas in spontaneously hypertensive rat. Basic Res. Cardiol. 101, 193-203 http://dx.doi.org/10.1007/s00395-005-0583-y

Pfeil U., Paddenberg R., Kummer W. (2006): Mitochondrial regulation of hypoxia-induced increase of adrenomedullin mRNA in HL-1 cells. Biochem. Biophys. Res. Commun. 343, 885-892 http://dx.doi.org/10.1016/j.bbrc.2006.03.042

Rakieten N., Rakieten M. L., Nadkarni M. V. (1963): Studies on the diabetogenic action of streptozotocin. Cancer Chemother. Rep. 29, 91-98

Regalia J., Cai F., Helke C. (2002): Streptozotocin-induced diabetes and the neurochemistry of vagal afferent neurons. Brain Res. 938, 7-14

http://dx.doi.org/10.1016/S0006-8993(02)02456-3

Rittenhouse P. A., Marchand J. E., Chen J., Kream R. M., Leeman S. E. (1996): Streptozotocin-induced diabetes is associated with altered expression of peptide-encoding mRNAs in rat sensory neurons. Peptides 17, 1017-1022 http://dx.doi.org/10.1016/0196-9781(96)00129-5 
Ruzicska E., Foldes G., Lako-Futo Z., Sarman B., Wellmann J., Szenasi G., Tulassay Z., Ruskoaho H., Toth M., Somogyi A. (2004): Cardiac gene expression of natriuretic substances is altered in streptozotocin-induced diabetes during angiotensin II-induced pressure overload. J. Hypertens. 22, 1191-1200 http://dx.doi.org/10.1097/00004872-200406000-00021

Saito A., Kimura S., Goto K. (1986): Calcitonin gene-related peptide as potential neurotransmitter in guinea-pig right atrium. Am. J. Physiol. 250, H693-698

Shimekake Y., Nagata K., Ohta S., Kambayashi Y., Teraoka H., Kitamura K., Eto T., Kangawa K., Matsuo H. (1995): Adrenomedullin stimulates two signal transduction pathways, cAMP accumulation and $\mathrm{Ca} 2+$ mobilization, in bovine aortic endothelial cells. J. Biol. Chem. 270, 4412-4417 http://dx.doi.org/10.1074/jbc.270.9.4412

Shimosawa T., Matsui H., Xing G., Itamura K., Ando K., Fujita T. (2003): Organ-protective effects of adrenomedullin. Hypertens. Res. 26, S109-112 http://dx.doi.org/10.1291/hypres.26.S109

Skopek P., Hynie S., Chottova Dvorakova M., Sida P., Slavikova J., Mistrova E., Klenerova V. (2012): Effects of acute stressors on the expression of oxytocin receptor mRNA in hearts of rats with different activity of HPA axis. Neuro Endocrinol. Lett. 33, 101-109

Tang F., Hwang I. S., Wong M.P, Li Y. Y. (2007): Adrenomedullin gene expression and peptide levels in the heart and blood vessels of streptozotocin-diabetic rats. Horm. Metab. Res. 39, 3-8 http://dx.doi.org/10.1055/s-2007-956517

Tixier E., Leconte C., Touzani O., Roussel S., Petit E., Bernaudin M. (2008): Adrenomedullin protects neurons against oxygen glucose deprivation stress in an autocrine and paracrine manner. J. Neurochem. 106, 1388-1403 http://dx.doi.org/10.1111/j.1471-4159.2008.05494.x

Toth C., Martinez J., Zochodne D. W. (2007): AGE, diabetes, and the nervous system. Curr. Mol. Med. 7, 766-776 http://dx.doi.org/10.2174/156652407783220705

Totsune K., Takahashi K., Mackenzie H. S., Murakami O., Arihara Z., Sone M., Mouri T., Brenner B. M., Ito S. (2000): Increased gene expression of adrenomedullin and adrenomedullin-receptor complexes, receptor-activity modifying protein (RAMP) 2 and calcitonin-receptor-like receptor (CRLR) in the hearts of rats with congestive heart failure. Clin. Sci. (Lond) 99, 541-546 http://dx.doi.org/10.1042/CS20000108

Tsuruda T., Kato J., Kitamura K., Kuwasako K., Imamura T., Koiwaya Y., Tsuji T., Kangawa K. (1998): Adrenomedullin: a possible autocrine or paracrine inhibitor of hypertrophy of cardiomyocytes. Hypertension 31, 505-510 http://dx.doi.org/10.1161/01.HYP.31.1.505

Tsuruda T., Kato J., Kitamura K., Imamura T., Koiwaya Y., Kangawa K., Komoro I., Yazaki Y., Eto T. (2000): Enhanced adrenomedullin production by mechanical stretching in cultured rat cardiomyocytes. Hypertension 35, 1210-1214 http://dx.doi.org/10.1161/01.HYP.35.6.1210

Wharton J., Gulbenkian S., Mulderry P. K., Ghatei M. A., McGregor G. P., Bloom S. R., Polak J. M. (1986). Capsaicin induces a depletion of calcitonin gene-related peptide (CGRP)-immunoreactive nerves in the cardiovascular system of the guinea pig and rat. J. Auton. Nerv. Syst. 16, 289-309 http://dx.doi.org/10.1016/0165-1838(86)90035-4

Zochodne D. W., Verge V., Cheng M. C., Sun J., Johnstan J. (2001): Does diabetes target ganglion neurones? Progressive sensory neurone involvement in long-term experimental diabetes. Brain 124, 2319-2334 http://dx.doi.org/10.1093/brain/124.11.2319

Zhao Y., Bell D., Smith L. R., Zhao L., Devine A. B., McHenry E. M., Nicholls D. P., McDermott B.S. (2006): Differential expression of components of the cardiomyocyte adrenomedullin/intermedin receptor system following blood pressure reduction in nitric oxide-deficient hypertension. J. Pharmacol. Exp. Ther. 316, 1269-1281 http://dx.doi.org/10.1124/jpet.105.092783

Received: July 1, 2013

Final version accepted: September 19, 2013 